\title{
Ellipsis
}

2014

\section{The American Question: The End of a Superpower?}

Karen Trundle

Follow this and additional works at: https://scholarworks.uno.edu/ellipsis

Part of the Nonfiction Commons

\section{Recommended Citation}

Trundle, Karen (2014) "The American Question: The End of a Superpower?," Ellipsis: Vol. 41 , Article 12. DOI: https://doi.org/10.46428/ejail.41.12

Available at: https://scholarworks.uno.edu/ellipsis/vol41/iss1/12

This Essay is brought to you for free and open access by the Department of English and Foreign Languages at ScholarWorks@UNO. It has been accepted for inclusion in Ellipsis by an authorized editor of ScholarWorks@UNO. For more information, please contact scholarworks@uno.edu. 


\section{The American Question: The End of a Superpower? Karen Trundle}

American supremacy, and its role in the world as a superpower, has been questioned for as long as it has been a reality. At the end of WWI the United States clearly came out on top as a superpower but by the end of WWII, it had a competitor for the top spot in the USSR. This system of bipolarity in the international system has been accredited with the Long Peace since, despite the regional conflicts that took place, the major powers of the time never directly battled each other. Ironically, it was during this time of competition that Americans seem to have been most confident of their powerful place in the world. Yet strangely, once the cold war had ended and the USSR collapsed, Americans began to fear that every nation that was doing well might be surpassing them. With the passing of communist red-baiting, Americans seem to have turned to the economy and education as the defining concept of what makes them powerful, and unfortunately, there have been scares in both of those fields.

This being said, I don't believe there will ever be an agreement on whether or not America is in decline or whether it will lose its top spot in the international arena because people do not seem to agree on what it means to be a superpower. Nonetheless, the American question, the possibility of the decline of American hegemony, can be looked at from quite a few different levels in order to understand its position: militarily, economically, ideologically, culturally and educationally. It is within these levels that the rise or fall of US power may be determined, as within them are distinct differences in what people perceive as power. Traditionally, power was vested in military prowess which, more often than not, relies on economic power, but more and more, it is soft power, which uses ideology, culture and education to name a few, that is forging the way. Soft power, a term coined by the foreign policy scholar Joseph Nye, refers to "the ability to affect others to obtain the outcomes one wants through attraction rather than coercion or payment" (Nye 94). Whether or not America remains the world's foremost superpower today will likely not be known until it is written about in the history books and superpower is defined by those who have come out on top.

As it turns out, fear of being toppled is not a new concept for Americans: "In the 1950s we worried that the Soviet Union would overtake us. In the 1980's we worried that Japan would become the number-one economic power" (Zakaria, xi). This fear or awareness, however you may see it, was something being observed by astute politicians and people alike during the Nixon era. Former 
Secretary of State Henry Kissinger, who had a keen eye for international relations, said that during his term that "a major reassessment of American foreign policy would have been in order, for the age of Americas nearly total dominance of the world stage was drawing to a close (Craig \& Logevall 253). Coming from a stillinfluential diplomat, the thought surely needs to be given some credence.

The military interventions that took place after 9/11, in Iraq and Afghanistan, and the subsequent reactions, are indicators that Kissinger's words may have come true. American "influence reached its apogee with Iraq. Despite the reluctance, opposition, or active hostility of much of the world, the United States was able to launch an unprovoked attack on a sovereign country and to enlist dozens of countries and international agencies to assist it during and after the invasion" (Zakaria 52). This clearly demonstrates the influence the United States had in the world. But it is this very same event that shook the world and awoke it to the absolute power of the United States. "This exercise of unipolarity...provoked a reaction around the world" (Zakaria 52). Anti-American sentiment broke out throughout Europe and other parts of the world. Although it is often reported as jealousy or an ideological difference, it seems as though unchecked American power has scared people.

This may have been a defining turning point. From this point forward, powers and rising powers alike seem to have stopped bowing to the United States every whim. Current evidence of this can be glimpsed in France and Israel's denouncement of the Iranian nuclear talks in November 2013, which were applauded by the United States. It is impossible to know whether or not these states would have spoken up in previous decades, but it could be an indicator of them no longer towing the American line. As Zakaria points out "the fact that new powers are more strongly asserting their interests is the reality of the postAmerican world" (39).

Apart from the Iranian nuclear talks, there are other indicators that the world may be no longer waiting for the United States' permission to take interstate action. The 2011 military intervention in Libya was largely initiated by France and the UK, with the US supporting but not leading the way. "France led the call for a Western attack on Libya in 2011" (Barzegar). Likewise, while the United States declined to intervene militarily in Syria due to public opinion at home, possibly fearing the same backlash as when they intervened in Iraq, France was taking a stern stance against the perpetrators of the chemical attacks of August 2013, openly calling for a UN mandate for military intervention (Barzegar).

The biggest global economic issue in recent decades, the worldwide depression, hit the United States and other countries hard, but this time the world did not turn to the US for help or advice. In fact "Europe's euro-crisis... might be the first international economic crisis since the 1920's in which the United States 
is essentially a bystander" (Zakaria xiii). Another oft cited reason to believe that the United States is slipping is education at primary, secondary, and college level. Last year, Time magazine ran a front-page story of how the Chinese have overtaken the United States in education, and it became a talking point on all TV talk shows for months. Soon afterwards the story of "Tiger Moms" - AsianAmerican mothers who pushed their children extremely hard to succeed in everything, became a fixation for all parents. The fear of another state's children outperforming ours has become the new red-scare for middle and upper class parents all over the United States.

Can these reasons truly be considered evidence of American decline? While reading The Post-American World by Zakaria, I was surprised to see that his first statement was an opinion I had long held myself: that it is "not about the decline of America but rather the rise of the rest" (Zakaria 1). Many new states were born during the Cold War and Cold War politics meant you either became communist or capitalist. However, lately "rising powers appear to be following a third way: entering the Western order but doing so on their own terms" (Zakaria 38). States now see benefits in other ways of doing things, and with help from international organizations such as the EU, the AU, the IMF and the World Bank, they can go it alone without having to make as many concessions to the United States as may once have been necessary in order to thrive. While not a new state, China has mixed it up in the world system to take advantage of capitalism while not completely switching to the American way of life.

If there is a challenger to the US's hegemonic position, it comes from China. Although they manipulate their currency to keep up in the world, and their human rights record leaves a lot to be desired, there is no denying their recent economic success. "The size of the [Chinese] economy has doubled every eight years for three decades" while economies all over the rest of the world, including the US, dropped (Zakaria 102). (Interestingly China was instrumental in helping the US eventually win the Cold War, when it broke ties with the USSR. Nixon and Kissinger used the Sino-Soviet rift to their advantage. They recognized that "China fit precisely within the strategy of redirecting American foreign policy away from bipolar power politics" (Craig \& Logevall 301).) Nevertheless, even recent Chinese achievements have not been enough to convince all academics of their overtaking the United States. "China [may] have become an important part of the supply chain-but still just a part" (Zakaria 202). "China will not replace the United States as the world's superpower. It is unlikely to surpass it on any dimension - military, political, or economic — for decades, let alone have dominance in all areas. But on issue after issue, it has become the second-mostimportant country in the world" (Zakaria 106).

There are many other reasons not to throw in the towel on the United States just yet. While there may be major problems, especially regarding internal 
gridlock in the political system, there is plenty of opportunity for improvement. There are also some natural, internal structures that will help the United States continue to be a superpower. Firstly the vast oil reserves in the US are largely untapped, which could become a huge advantage in the future. Also, unlike most of the rest of the world's population, the United States does not, as of yet, have an issue with an ageing population. There is a huge problem growing in Europe and in China while in the United States, children continue to outnumber the elderly (Zakaria 213). This is tantamount for keeping the economy on track in the long run. Future technology is also a huge helping hand for the United States Economy. "Look at the industries of the future. Nanotechnology...is considered likely to lead to fundamental breakthroughs over the next fifty years [and]... the United States dominates the field" (Zakaria 200-201).

Education is also not as bad as it is made out to be by the press. Despite an obvious decline in the education system over the past years, "the United States absolutely dominates higher education, having either 74 or 54 percent the world's top fifty universities" (Zakaria 207). (This being said it is important to note that about 50 percent of PhD's awarded in the United States are given to international students. These students are the future of research, and to succeed, the United States must make better efforts to keep these students in the country (Zakaria 215).

Worst case scenario, even if the United States does not have the economic growth that China does right now it may not be the end of supremacy. "Britain managed to maintain its position as the leading world power for decades after it lost its economic dominance, thanks to a combination of shrewd strategic outlook and good diplomacy" (Zakaria 194). And there is no denying that United States diplomacy has taken a slight turn with the election of President Obama. The recent diplomatic talks with Iran concerning their nuclear capabilities is just one of the signs of a turn in US foreign policy which also "fulfills a campaign pledge [by President Obama] from 2008 that he would stretch out a hand to America's enemies and speak to any foreign leader without preconditions" (Landler). "'We're testing diplomacy; we're not resorting immediately to military conflict,' Mr. Obama said, defending the Iran deal" (Landler). This recent turn to soft power is instrumental in the new type of diplomacy needed to remain a superpower.

Oddly enough, many of the reasons that people cite as evidence of other states becoming stronger than the United States, are issues that we have been fighting for decades. Initially an isolationist state, it was morals, the right of freedom for all people, which eventually dragged the United States into war and onto the stage as superpower. "The irony is that the rise of the rest is a consequence of American ideas and actions" (Zakaria 60). The majority of Americans want to see the rest of the world succeed. This can be seen in the 
enormous aid efforts that they put forward. But this goal may have harmed them also. Extremists and naysayers like to use American-styled globalization as evidence that America is taking over the world. But "it all looks American because America, the country that invented mass capitalism and consumerism, got there first" (Zakaria 91). It was not necessarily a huge covert soft power operation.

When it comes down to it, the definition of superpower has changed, as has the role of the hegemonic state. "Global power is [now], above all, dominance over ideas, agendas, and models" (Zakaria 49). Statesmen have realized that this has been changing for quite some time. The father of containment, George F. Keenan once said, "Perhaps a strategy of containment... should now be targeted not so much at a foreign adversary but at an American political system that threatens to undermine a hard-fought cold war victory from within." "It could in fact be said," Kennan concluded, "that the first thing we Americans need to learn to contain is, in some ways, ourselves" (Craig \& Logevall 370). Many of the recent past presidents and statesmen either genuinely felt that the United States needed to back away from overbearing power, or pretended that they felt that way. President Regan said, of the end of the Cold War, that he had merely "been dropped into a grand historical moment" (Craig \& Logevall 345). President Carter "felt certain that US foreign policy should reflect the new, more multipolar international system" (Craig \& Logevall 296). During Secretary of State Clinton's confirmation, she said that the new administration would "elevate pragmatism over ideology, partnerships over unilateralism, and diplomacy over the use of force" (Merrill \& Paterson 554). "This new role is quite different from the traditional superpower role. It involves consultation, cooperation, and even compromise. It derives its power by setting the agenda, defining the issues, and mobilizing coalitions" (Zakaria 258). Ironically it is this new role of soft power that may in fact stop the United States from no longer being a power at all.

Having discussed the ins and outs of the American Question as I call it, it would seem I am no closer to an answer. Whether or not we are in a postAmerican world will depend on how you cut it. One thing that is certain is that nothing is going to dramatically change overnight. "Great powers are like divas: they enter and exit the international stage with great tumult" (Zakaria 117). The best thing that can be done is to remember that "America embraced international cooperation not out of fear and vulnerability but out of confidence and strength" (Zakaria 254). Sure, there are going to be people who will dislike the United States, no matter what, but if we can keep our eye on why we originally intervened in the world, on moral grounds, we cannot go wrong. We should not be alarmed at the growth of other states; we should be proud. "Americans take justified pride in their own country-we call it patriotism-and yet are genuinely startled when other people are proud and possessive of theirs" (Zakaria 36). 
Undoubtedly we have made some decisions based on opportunism but these decisions have been largely made by those in charge. It is up to the American population to be aware of who we are electing and how they represent us. By doing this we will be safe. "The task for Barack Obama and future presidents is to construct a new approach for a new era, one that responds to a global system in which power is far more diffuse than ever before and in which everyone feels empowered" (Zakaria 256). For the time being the United States "remains, in the words of the German writer Josef Joffe, the default superpower" (Zakaria 53). 


\section{Works Cited}

Barzegar, Karine G. "Analysis: France's hawkish stand on Syria a pattern.” USA Today. 8 Sept. 2013. Web. 24 Jan. 2014.

Craig, Campbell, and Fredrik Logevall. America's Cold War: The Politics of Insecurity. Cambridge: Harvard UP, 2009. Print.

Landler, Mark. "Obama Signals a Shift from Military Might to Diplomacy." The New York Times. 25 Nov. 2013. Web. 24 Jan. 2014.

Merrill, Dennis, and Thomas G. Paterson, eds. Major Problems in American Foreign Relations, Volume II: Since 1914. Boston: Wadsworth, 2010. Print.

Nye, Joseph S. "Public Diplomacy and Soft Power. American Academy of Political and Social Science. Vol. 616 (2008): 94-109. JSTOR. Web. 24 Jan. 2014.

Zakaria, Fareed. The Post-American World. New York: Norton, 2012. Print. 